\title{
Incorporation of brown tide into an estuarine food web
}

\author{
Greg T. Street, Paul A. Montagna*, Patrick L. Parker \\ University of Texas, Marine Science Institute, 750 Channelview Drive, Port Aransas, Texas 78373, USA
}

\begin{abstract}
In Laguna Madre, Texas, USA, a monospecific brown tide bloom began in January 1990 and was still persisting at the time of this writing. Immediately following the start of the bloom, abundance, biomass and diversity of benthos declined, and have remained low for 6 yr. One explanation for the decline is that the brown tide organism is a poor food source. To determine whether the brown tide was incorporated into the estuarine food web, benthic invertebrates and fish were studied 14 mo after the bloom onset using stable carbon isotope ratios. Fish and benthos were collected from 2 areas, a seagrass habitat in Laguna Madre, and a muddy bottom habitat in the adjacent Alazan Bay. The muddy bottom fauna had a strong brown tide signature, indicating the incorporation of brown tide or brown tide detritus into the food web. The higher-biomass seagrass-fauna had heavier isotope values, reflecting incorporation of seagrass carbon in addition to brown tide. The top predators, Sciaenops ocellatus and Pogonias cromis, have different niches, but were able to switch food sources and thrive during the brown tide bloom. Brown tide appears to be able to support an estuarine food web, but at the expense of benthic diversity. The loss of benthic diversity could be due to allelopathy or the inability of some species to assimilate brown tide. Habitats with extensive seagrass beds maintain higher productivity and diversity than muddy habitats. However, seagrass habitats are endangered because brown tide reduces light levels, inhibits seagrass growth, and is causing seagrass decline.
\end{abstract}

KEY WORDS: Benthos Brown tide Food webs Seagrass - Stable carbon isotopes

\section{INTRODUCTION}

Estuarine ecosystems often experience stochastic events that have the potential to disrupt community stability. Brown tides, monospecific blooms of certain species of phytoplankton, have been responsible for major alterations in community structure in some estuaries. In Long Island Sound (USA), Naragansett Bay (USA), and Laguna Madre, Texas (USA), brown tides have been responsible for dramatic losses of species abundance and diversity, particularly of shellfish (Bricelj et al. 1987, Cosper et al. 1987, Shumway 1990, Montagna et al. 1993, Buskey et al. 1996). Allelopathic effects have been documented for some brown tide events (Draper et al. 1989, Tracey et al. 1990, Gainey \&

\footnotetext{
- Addressee for correspondence.

E-mail:paul@utmsi.zo.utexas.edu
}

Shumway 1991). Brown tide may also negatively impact communities by reducing light levels (Dunton 1994, DeYoe \& Suttle 1994), clogging filter-feeding mechanisms or presenting animals with a poor quality food source (Tracey 1988, Bricelj \& Kuenstner 1989, Buskey \& Stockwell 1993). These negative effects can alter community structure by eliminating certain species

The Texas brown tide organism is a small ( 4 to $5 \mu \mathrm{m}$ in diameter) previously unknown species of the newly recognized class Pelagophyceae (Andersen et al. 1993, DeYoe \& Suttle 1994). The effects of the Texas brown tide are similar to those that occurred in Naragansett Bay and Long Island Sound in that the loss of benthic species abundance and diversity took place after the onset of the algal bloom (Conley 1996). However, unlike previous brown tides, the Texas brown tide organism does not seem to have toxic effects upon adult fish or invertebrates (Buskey \& Stockwell 1993, 
Buskey et al. 1996). Therefore, it is likely that the brown tide alters community structure through other mechanisms, such as altered trophic dynamics. During the bloom, the brown tide was the dominant phytoplankton in the water column by several orders of magnitude (Buskey \& Stockwell 1993), attaining cell densities of $10^{9} \mathrm{l}^{-1}$ (Stockwell et al. 1993) and leading to chlorophyll concentrations that fluctuated from 10 to $70 \mathrm{\mu g} \mathrm{l}^{-1}$ from 1989 to 1993 (D. Stockwell unpubl.). The large concentration of particulate matter in the water reduced the amount of light available for photosynthesis, resulting in a loss of $9.4 \mathrm{~km}^{2}$ from $140 \mathrm{~km}^{2}$ of seagrass habitat (Onuf 1996a). Benthic production by microalgae was similarly affected, decreasing from $3 \mathrm{~g} \mathrm{C}$ $\mathrm{m}^{-2} \mathrm{~d}^{-1}$ to virtually nothing (Blanchard \& Montagna 1992). Despite a high standing stock, the brown tide may not have been trophically available. The brown tide Aureococcus anophagefferens can clog the filterfeeding devices oí bivalves, affecting feeding (Briceij \& Kuenstner 1989, Shumway 1990). However, the Texas brown tide can be assimilated by the dominant bivalve in Texas estuaries, Mulinia lateralis (Montagna et al.

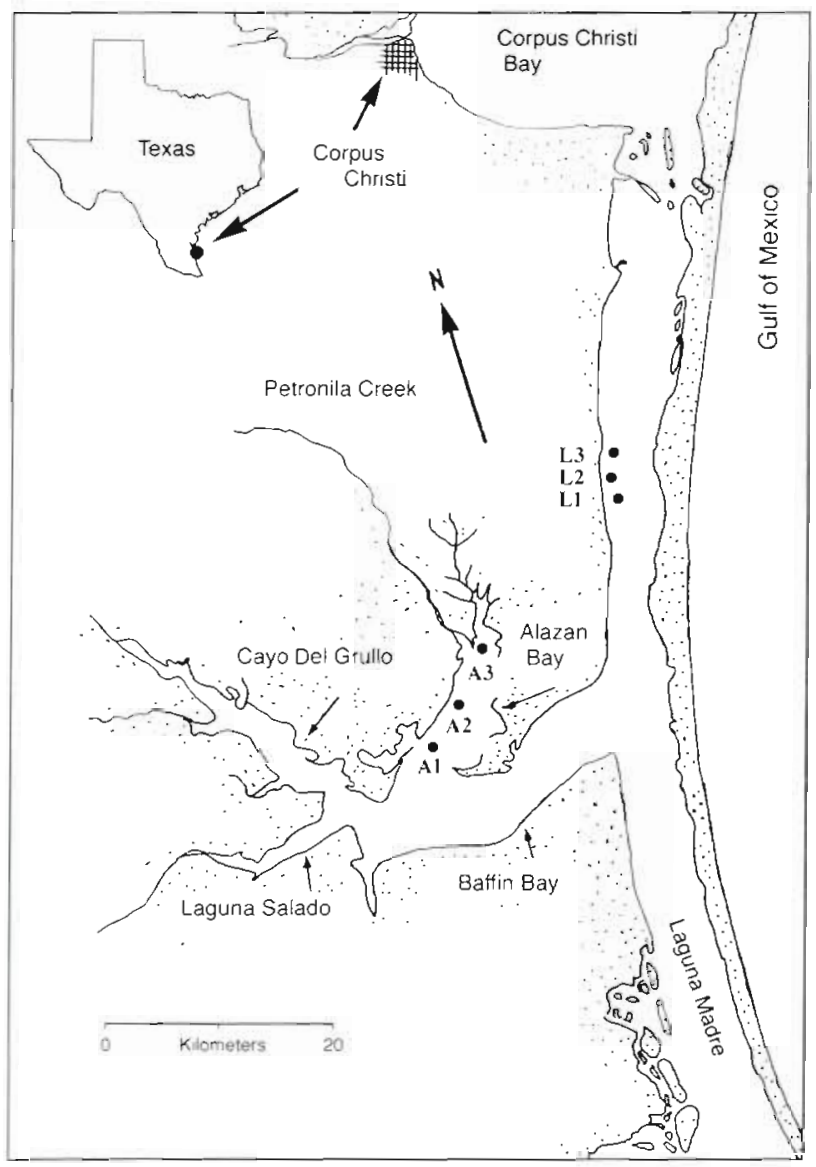

Fig. 1. Study area showing sampling stations in the 2 study bays, Alazan Bay and Laguna Madre, Texas, USA
1993). M. lateralis consumed and assimilated the brown tide alga at rates comparable to rates for Isochrysis galbana, Dunaliella tertiolecta and Heterocapsa pygmeae (Montagna et al. 1993). However, it is unknown if the benthic community in general can utilize the Texas brown tide as a food source. The brown tide was practically the only phytoplankton species available (Buskey \& Stockwell 1993), so inability to utilize brown tide as food could account for the loss of benthic abundance and diversity.

The objective of the current study was to determine if brown tide was being incorporated into the estuarine food web, and if changes in benthic community structure could be related to a trophic link with brown tide. Community structure was compared in 2 bays with different dominant benthic habitats and different dominant carbon sources. Alazan Bay is dominated by phytoplankton (brown tide) and Laguna Madre is dominated by seagrass. Stable carbon isotope ratios were measured in consumers (benthos and fish) and compared to potential carbon producers and sources (brown tide, seagrass and sediment). The stomach contents of 2 dominant fish species were identified to determine if loss of certain benthic taxa altered what the fish were eating and to help interpret the isotope ratios of fishes. Food webs that incorporate brown tide could produce a different community structure than food webs that do not incorporate brown tide. Brown tide could have different effects in different habitats.

\section{MATERIALS AND METHODS}

Study area. The study was performed in the hypersaline bays Upper Laguna Madre and Alazan Bay, in south Texas, USA (Fig. 1). Alazan Bay is a tertiary arm of Baffin Bay. The 3 arms of Baffin Bay (which receive intermittent freshwater via creeks) and the Laguna Madre (which has connections to the Gulf of Mexico) make up the Laguna Madre Estuary. Only 4 other hypersaline estuaries, which receive freshwater and maintain a tidal connection with the sea, have been studied (Javor 1989). They are the Putrid Sea, or the Sivash, a large $\left(2700 \mathrm{~km}^{2}\right)$ arm of the Sea of Azov (Ukraine), the Laguna Ojo de Liebre (about $50 \mathrm{~km}$ long), on the Pacific coast of Baja California (Mexico), Spencer Gulf (South Australia), and Shark Bay (Western Australia). In Laguna Madre, high evaporation rates and low inflow rates lead to hypersaline conditions (Texas Department of Water Resources 1988). Circulation rates are very low because the region is microtidal, inflow is limited, and passes are up to $200 \mathrm{~km}$ from the headwaters of Baffin Bay. There are no extensive saltmarshes around Laguna Madre, but seagrass beds are extensive. Carbon derived from 
oceanic sources is also relatively unimportant in Baffin Bay and the Upper Laguna Madre because of great distances from Gulf passes. Alazan Bay has a predominantly muddy bottom, and phytoplankton represents the major source of primary production. Laguna Madre has extensive seagrass beds of Halodule wrightii and Thalassia testudinum. Algal epiphytes are seldom observed on seagrasses in Laguna Madre (Jewett-Smith 1991). Therefore, phytoplankton and seagrasses represent the major sources of primary production in the Laguna Madre ecosystem. During the study period, concentrations of brown tide were so high that it effectively replaced all other phytoplankton throughout the entire ecosystem (Buskey \& Stockwell 1993).

Sampling and analyses. Sampling was conducted in the 2 bays, Alazan Bay (A) and Laguna Madre (L), with 3 sampling stations $(1,2,3)$, located 1 to $5 \mathrm{~km}$ apart, within each bay (Fig. 1). All samples were taken between 16 and 18 April 1991. The brown tide began in Alazan Bay in January 1990, and had spread to Laguna Madre by July 1990, so sampling was performed 8 to 16 mo after the bloom began. Surface and bottom profiles of temperature, salinity, $\mathrm{pH}$, dissolved oxygen, oxidation-reduction potential, conductivity and depth were measured using a Hydrolab 4000 .

All stations were sampled for quantitative macroinfauna analyses. In Alazan Bay, 9 replicate cores were taken per station. In Laguna Madre, 3 replicate sediment cores were taken per station. Sediment cores were collected to a depth of $10 \mathrm{~cm}$ with a $6.7 \mathrm{~cm}$ diameter tube held by divers. Samples were preserved in $5 \%$ buffered formalin, retained on a $500 \mu \mathrm{m}$ sieve, and identified under a dissecting microscope to the lowest possible taxon. After identification, organisms were pooled into samples of higher taxa (i.e. nemertean, mollusk, polychaete or crustacean), dried at $55^{\circ} \mathrm{C}$ for $24 \mathrm{~h}$, and weighed. Before drying, mollusks were placed in $1 \mathrm{~N} \mathrm{HCl}$ for 1 min to $8 \mathrm{~h}$ (depending on size) and then rinsed to remove carbonate shells.

Qualitative collections for stable isotope analyses on macrofauna and small fish were made using seines and shovels at all stations. Infauna sampling was performed by collecting approximately $0.5 \mathrm{~m}^{2}$ of the top $5 \mathrm{~cm}$ of sediment with a shovel at each of these stations. These animals were sieved live on a $500 \mu \mathrm{m}$ mesh and identified to the lowest possible taxon. A $10 \mathrm{~m}$ seine was used to collect small fish and large. mobile epifauna. The animals collected were sorted and identified live, and a sub-sample was kept frozen for isotopic analysis.

Large fish were collected from gill nets from Stns A1, A2, A3 and L3. Gill nets were employed in cooperation with the Texas Parks and Wildlife Department Coastal Fisheries Division as part of their routine finfish stock assessment program. The gill nets were $183 \mathrm{~m}$ long by
$1.2 \mathrm{~m}$ deep, used a varying mesh size of 7.6 to $15.2 \mathrm{~cm}$ and were deployed overnight (Texas Parks and Wildlife 1993). The digestive tract was removed from live or recently dead fish (determined by inspection of gill color) and preserved in $10 \%$ buffered formalin. The contents were washed onto a $240 \mu \mathrm{m}$ sieve and identified to the lowest possible taxon under a dissecting microscope. The dominant fish, the black drum Pogonias cromis was often filled to capacity with broken mollusk shells. Therefore, quantitative measurements were used in lieu of volumetric measurements. Individual prey organisms were enumerated. Mollusk shells were counted only when both valves were present and attached at the umbo. Only heads were counted for other vertebrate and invertebrate prey.

Sub-samples of macrofauna (collected from cores, seines and shovels) and fish (collected from seines and gill nets) were saved for stable isotope analysis. Samples of the 3 dominant carbon sources were also collected: seagrass, brown tide and bay sediment. For fish larger than $0.8 \mathrm{~g}$ dry weight, a sample of muscle tissue was removed from the organism. For fish and invertebrates smaller than $0.8 \mathrm{~g}$ dry body weight, the tissue sample was composed of several individuals from a single species. Carbonate present in invertebrate samples was dissolved with $\mathrm{H}_{2} \mathrm{PO}_{4}$ prior to drying. All stable isotope samples were dried at $80^{\circ} \mathrm{C}$ and ground to a fine powder The sample was then combusted in contact with $\mathrm{CuO}$ in sealed, evacuated borosilicate glass tubes at $590^{\circ} \mathrm{C}$ for $2 \mathrm{~h}$ (Sofer 1980). The resulting $\mathrm{CO}_{2}$ was purified by distillation under vacuum using a dry ice/ethanol slurry and liquid nitrogen. Evolved $\mathrm{CO}_{2}$ was analyzed on a mass spectrometer (Parker 1964, Trust 1993). All data are expressed in $\delta^{13} \mathrm{C}$ units relative to the PDB standard (Craig 1957) where $\delta^{13} \mathrm{C}=$ sample/standard $\times 10^{3}$. The precision for combustion and carbon isotopic analysis is $\pm 0.2 \%$ (Parker 1964 , Fry et al. 1977).

All organisms were classified into trophic groups (filter feeder, deposit feeder, herbivore or predator) and habitat groups (infauna, epifauna or nekton). Filter feeders were defined as benthos that possess filterfeeding structures and are generally assumed to feed on particulate matter from the water column. Planktivorous fish (e.g. Gulf menhaden Brevoortia patronus) were also included in this category. Deposit feeders included both selective and non-selective taxa and were defined as organisms that process sediment. Herbivores included grazing organisms that feed on macrophytes, encrusting algae, seagrass or seagrass detritus, and included macrobenthos (e.g. amphipods) and herbivorous fish (e.g. pinfish Lagodon rhomboides).

Statistical analysis. An analysis of variance (ANOVA) was performed on macrofauna abundance 
Table 1. Mean species abundance ( 1 nd. $\mathrm{m}^{-2}$ ) to a depth of $10 \mathrm{~cm}$ in the sediment in the 2 study bays (Texas, USA). SD: standard deviation; P: phylum; SP: subphylum; C: class; O: order

\begin{tabular}{|c|c|c|c|c|}
\hline \multirow{2}{*}{ Taxon } & \multicolumn{2}{|c|}{ Alazan Bay } & \multicolumn{2}{|c|}{ Laguna Madre } \\
\hline & Mean & SD & Mean & $\mathrm{SD}$ \\
\hline \multicolumn{5}{|l|}{ P: Rynchocoela } \\
\hline Rhynchocoela (unidentified) & 0 & 0 & 142 & 257 \\
\hline \multicolumn{5}{|l|}{ P: Mollusca } \\
\hline \multicolumn{5}{|l|}{ C: Gastropoda } \\
\hline Caecum pulchellum & 0 & 0 & 1040 & 1507 \\
\hline Ceritheum Jutosum & 0 & 0 & 24 & 82 \\
\hline \multicolumn{5}{|l|}{ C: Pelecypoda } \\
\hline Anomalocardia auberiana & 0 & 0 & 118 & 283 \\
\hline Mulinia lateralis & 0 & 0 & 24 & 82 \\
\hline Tellina tampaensis & 0 & 0 & 118 & 255 \\
\hline \multicolumn{5}{|l|}{ P: Annelida } \\
\hline \multicolumn{5}{|l|}{ C: Polychaeta } \\
\hline Brania furcelligera & 0 & 0 & 307 & 520 \\
\hline Capitella capitata & 74 & 202 & 591 & 760 \\
\hline Chonesp. & 0 & 0 & 95 & 185 \\
\hline Eteone heteropoda & 0 & 0 & 24 & 82 \\
\hline Exogonesp. & 0 & 0 & 71 & 1.28 \\
\hline Haploscoloplos foliosus & 0 & 0 & 4254 & 4715 \\
\hline Heteromastus filiformis & 0 & 0 & 355 & 556 \\
\hline Nainereis sp. A & 0 & 0 & 24 & 82 \\
\hline Opisthosyllis sp. & 0 & 0 & 402 & 1029 \\
\hline Polydora ligni & 168 & 286 & 142 & 226 \\
\hline Schistomeringos rudolphi & 0 & 0 & 24 & 82 \\
\hline Streblospio benedicti & 8434 & 7498 & 95 & 185 \\
\hline \multicolumn{5}{|l|}{ C: Oligochaeta } \\
\hline Oligochaete (unidentified) & 0 & 0 & 402 & 610 \\
\hline \multicolumn{5}{|l|}{ SP: Crustacea } \\
\hline \multicolumn{5}{|l|}{ C: Malacostraca } \\
\hline \multicolumn{5}{|l|}{ O: Natantia } \\
\hline Palaemonetes sp. & 0 & 0 & 24 & 82 \\
\hline \multicolumn{5}{|l|}{ O: Amphipoda } \\
\hline Amphilochus sp. & 0 & 0 & 24 & 82 \\
\hline Corophium Iouisianum & 977 & 2701 & 24 & 82 \\
\hline Cymadusa compta & 0 & 0 & 24 & 82 \\
\hline Gammarus mucronatus & 0 & 0 & 142 & 257 \\
\hline Grandidierella bonnieroides & 2207 & 5111 & 236 & 433 \\
\hline \multicolumn{5}{|c|}{ O: Tanaidacea } \\
\hline Leptochelia rapax & 95 & 438 & 307 & 444 \\
\hline Total & 11955 & 10458 & 9033 & 5857 \\
\hline
\end{tabular}

and biomass to test for bay effects, using a nested design, with stations nested within bays. The residuals from the model were normally distributed for both abundance $(W=0.9484, p=0.1021)$ and biomass ( $W=$ $0.9421, p=0.0609$ ). Tukey's multiple comparison procedures were used to test for significant differences among station abundance and biomass. An ANOVA was performed on carbon isotope values to test for station differences by trophic and habitat groups. Tukey tests were used to test for significant differences among stations, trophic groups and habitat groups. All analyses were performed using SAS software (SAS Institute Inc. 1991).

\section{RESULTS}

\section{Hydrography}

Alazan Bay and Laguna Madre had similar hydrographic conditions. Water depth was greater for Laguna Madre $(1 \mathrm{~m})$ than for Alazan Bay $(0.3 \mathrm{~m})$. Average dissolved oxygen at the Laguna Madre stations bordered on hypoxia $\left(2.5 \mathrm{mg} \mathrm{l}^{-1}\right)$ compared to Alazan Bay (5.9 $\mathrm{mg} \mathrm{l}^{-1}$ ). Low oxygen concentrations are common in the morning over seagrass beds because of the large amount of biomass that respires at night. By mid-morning oxygen production by seagrasses has saturated the water column, so benthic effects due to oxygen differences are not expected to be important. During the time of sampling, both bay sites were hypersaline, with the Laguna Madre slightly more saline $(47.6 \%$ ) than Alazan Bay $(43.9 \%$ ).

\section{Macrofauna}

For both Alazan Bay and Laguna Madre, macrofauna abundance variance within a bay among stations was higher than variance between bays. Therefore, there was no significant difference in macrofauna abundance between Alazan Bay (11955 $\mathrm{m}^{-2}$ ) and Laguna Madre $\left(9033 \mathrm{~m}^{-2} ; \mathrm{p}=\right.$ 0.6188 ; Table 1$)$. There was a difference in mean biomass ( $\mathrm{p}=0.0001$ ); Laguna Madre values were 5 times higher $\left(4.90 \mathrm{~g} \mathrm{~m}^{-2}\right)$ than those in Alazan Bay $\left(0.71 \mathrm{~g} \mathrm{~m}^{-2}\right.$; Table 2). Laguna Madre also had more seagrass biomass $\left(522 \mathrm{~g} \mathrm{~m}^{-2}\right)$ than did Alazan Bay ( $79 \mathrm{~g} \mathrm{~m}^{-2}$; Table 2). Species composition and diversity were different between the 2 bays. Only polychaetes and crustacea were found in Alazan Bay (Tables 1 \& 2). Only 6 species of macrofauna were found in Alazan Bay, while 27 species were found in Laguna Madre (Table 1). The average Shannon-Weaver diversity index

Table 2. Mean benthic biomass ( $g$ dry weight $\mathrm{m}^{-2}$ ) to a depth of $10 \mathrm{~cm}$ by taxon

\begin{tabular}{|c|c|c|c|c|}
\hline \multirow[t]{2}{*}{ Taxa } & \multicolumn{2}{|c|}{ Alazan Bay } & \multicolumn{2}{|c|}{ Laguna Madre } \\
\hline & Mean & SD & Mean & $\mathrm{SD}$ \\
\hline Nemertean & 0.0 & 0.0 & 0.02 & 0.04 \\
\hline Mollusk & 0.0 & 0.0 & 1.17 & 2.25 \\
\hline Polychaete & 0.49 & 0.35 & 3.67 & 4.37 \\
\hline Crustacean & 0.22 & 0.47 & 0.04 & 0.07 \\
\hline Total animal & 0.71 & 0.69 & 4.90 & 6.02 \\
\hline Seagrass & 78.8 & 105.2 & 522.06 & 459.4 \\
\hline
\end{tabular}


was also lower for Alazan Bay $\left(H^{\prime}=0.880\right)$ than for Laguna Madre $\left(H^{\prime}=2.107\right)$, even though mean density at each site was not different. There were no mollusks in Alazan Bay, although Laguna Madre had 6 species of bivalves and gastropods. All species in Alazan Bay also occurred in the Laguna Madre, indicating that the Alazan Bay community is a subset of the Laguna Madre Estuary community. The dominant species were the spionid polychaete Streblospio benedicti in Alazan Bay, and the orbinid polychaete Haploscoloplos foliosus in Laguna Madre.

Table 3. $\delta^{13} \mathrm{C}$ values for species in each bay. The overall mean is an unweighted average of $\delta^{1.3} \mathrm{C}$ values. The weighted mean was calculated based on sample size per taxon $(n)$. D: deposit feeder; $F$ : filter feeder (includes planktivorous fish); $\mathrm{H}$ : herbivore; P: predator. Small infaunal organisms $(<0.8 \mathrm{~g})$ were pooled to create a sample

\begin{tabular}{|c|c|c|c|c|c|}
\hline \multirow[t]{2}{*}{ Taxon } & \multirow[t]{2}{*}{ Trophic group } & \multicolumn{2}{|c|}{ Alazan Bay } & \multicolumn{2}{|c|}{ Laguna Madre } \\
\hline & & & $\mathrm{n}$ & $\delta^{13} \mathrm{C}$ & $\mathrm{n}$ \\
\hline \multicolumn{6}{|l|}{ Mollusca } \\
\hline Caecum pulchellum & $\mathrm{D}$ & & & -14.8 & 2 \\
\hline Ceritheum lutosum & $\mathrm{H}$ & & & -13.4 & 5 \\
\hline \multicolumn{6}{|l|}{ Annelida } \\
\hline Heteromastus filiformis & $\mathrm{D}$ & -19.7 & 1 & & \\
\hline Nainereis laevigata & $\mathrm{P}$ & & & -14.9 & 1 \\
\hline Nereis sp. epitoke & $\mathrm{P}$ & -17.6 & 2 & & \\
\hline Opisthosyllis $\mathrm{sp}$ & $\mathrm{D}$ & & & -14.7 & 2 \\
\hline Polydora ligni & $\mathrm{F}$ & -16 & 1 & & \\
\hline Streblospio benedicti & $F, D$ & -18.2 & 3 & & \\
\hline \multicolumn{6}{|l|}{ Crusteacea } \\
\hline Callinectes sapidus & $\mathrm{P}$ & & & -11.6 & 5 \\
\hline Corophium louisianum & $\mathrm{D}$ & -18.3 & 4 & & \\
\hline Cymadusa compta & $\mathrm{H}$ & & & -10.1 & 6 \\
\hline Gammarus mucronatus & $\mathrm{H}$ & & & -10.9 & 5 \\
\hline Grandidierella bonnieroides & $\mathrm{H}$ & -16.5 & 7 & -10.9 & 1 \\
\hline Oxyurostylis salioni & $D$ & & & -13.1 & 1 \\
\hline Palaemonetes vulgaris & $\mathrm{H}$ & -14.2 & 15 & & \\
\hline \multicolumn{6}{|l|}{ Echinodermata } \\
\hline Holothuroida (unknown) & $\mathrm{D}$ & & & -9.9 & 3 \\
\hline \multicolumn{6}{|l|}{ Osteichthyes } \\
\hline Arius felis & $\mathrm{P}$ & & & -12.6 & 7 \\
\hline Bairdiella chrysura & $\mathrm{P}$ & -17.1 & 1 & & \\
\hline Brevoortia patronus & $\mathrm{F}$ & -18.5 & 10 & & \\
\hline Cyprinodon vareigatus & H.P & & & -9.7 & 5 \\
\hline Cynoscion nebulosus & $\mathrm{P}$ & -15.4 & 6 & & \\
\hline Dorosoma cepedianum & $\mathrm{F}$ & -15.0 & 1 & & \\
\hline Elops saurus & $\mathrm{P}$ & & & -12.8 & 5 \\
\hline Fundulus grandis & $\mathrm{H}, \mathrm{P}$ & & & -10.8 & 3 \\
\hline Gobionellus boleosoma & $P$ & -15.4 & 1 & & \\
\hline Lagodon rhomboides & $\mathrm{P}$ & -13.4 & 2 & -13.3 & 2 \\
\hline Leiostomus xanthurus & $\mathrm{P}$ & & & -10.0 & 4 \\
\hline Lucania parva & $\mathrm{H}, \mathrm{P}$ & & & -13.1 & 4 \\
\hline Membras martinica & F,P & -16.9 & 10 & -12.9 & 3 \\
\hline Mugil cephalus & $\mathrm{H}$ & -13.5 & 3 & -12.9 & 2 \\
\hline Pogonias cromis & $\mathrm{P}$ & -14.8 & 38 & -13.6 & 31 \\
\hline Sciaenops ocellatus & $P$ & -14.2 & 8 & -11.2 & 30 \\
\hline Syngnathus scovelli & $\mathrm{F}$ & -14.2 & 1 & & \\
\hline Overall mean & & -15.6 & 114 & -12.4 & 132 \\
\hline Mean weighted by trophic grou & & -16.6 & 4 & -13.7 & 4 \\
\hline
\end{tabular}

\section{Stable carbon isotopes}

Stable carbon isotope ratios were measured for 33 taxa, representing 5 phyla (Table 3). Because the minimum sample weight for the analysis was $0.8 \mathrm{~g}$, not as many values for benthos as for fish were available. Values ranged from -19.7 , for the deposit feeding polychaete Heteromastus filiformis, to -9.9 for an unidentified species of burrowing holothuroid. Organisms in Alazan Bay had more-negative values (representing a depietion in ${ }^{13} \mathrm{C}$ ) than organisms in Laguna Madre. The only exception was the pinfish Lagodon rhomboides, which had the same value in both bays. There were significant differences in carbon values between the 2 bays and among trophic groups (Fig, 2). When all values were pooled, Laguna Madre had a less-negative value than Alazan Bay, both overall ( -15.6 for Alazan vs -12.4 for Laguna) and weighted by trophic group ( -16.6 for Alazan vs -13.7 for Laguna; Table 3). There were significant differences in carbon isotope values among the 4 trophic groups $(\mathrm{p}=0.0001)$. Filter feeders $(-17.0)$ and deposit feeders $(-15.3)$ were not significantly different (Tukey's test), and predators (-13.9) and herbivores $(-13.0)$ were not significantly different. Predators and deposit feeders were not different from each other, but predators and filter feeders were different, and deposit feeders and herbivores were different. Within a particular trophic group, significant differences existed in deposit feeders $(\mathrm{p}=0.0035)$ between Alazan $(-18.7)$ and Laguna Madre (-13.1), in filter feeders $(p=0.0001)$ between Alazan $(-17.8)$ and Laguna Madre (-12.9) and in predators $(\mathrm{p}=0.0001)$ between Alazan (-14.0) and Laguna Madre $(-11.9)$. There was no difference in carbon isotope values between herbivores within the 2 bays. The $\delta^{13} \mathrm{C}$ value for sediment varied between the 2 bays (Fig. 2). Alazan Bay sediment (-18.8) was more negative than Laguna Madre sediment (-16.8). Trophic group $\delta^{13} \mathrm{C}$ values for Laguna Madre fell halfway between the signatures for seagrass and sediment. The sediment value for Laguna fell between those of brown tide and seagrass. 


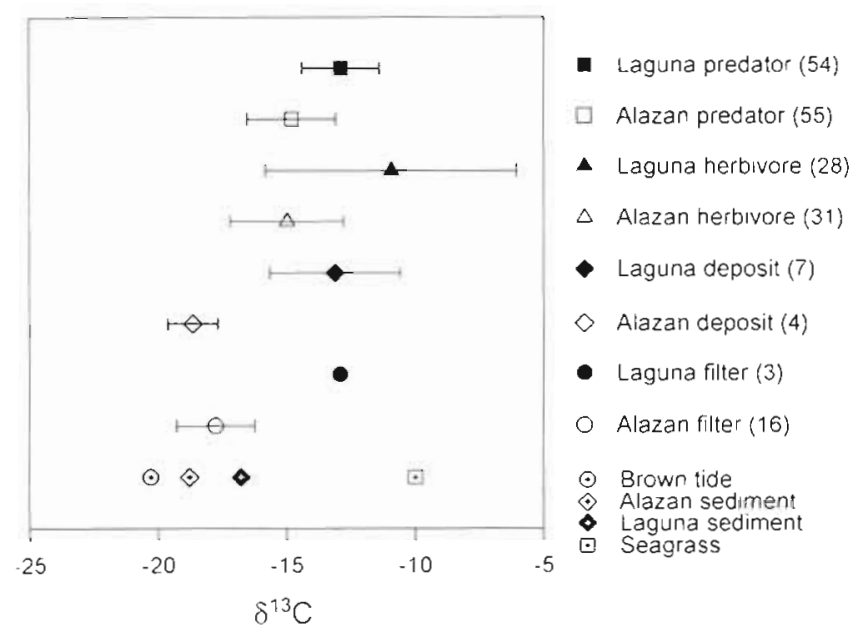

Fig. 2. Stable carbon isotope ratios for sources, macrofauna and fish by trophic group. Average and SD for all samples taken within a sampling area (sample size in parentheses). Filled symbols: Laguna Madre; open symbols: Alazan Bay

Trophic group $\delta^{13} \mathrm{C}$ values were more positive than the values for sediment for both bays (Fig. 2).

There were significantly different isotope values among habitat groups (i.e. infauna, epifauna and fish; $p=0.0128 ;$ Fig. 3). Epifauna and fish had a similar mean $\delta^{13} \mathrm{C}(-13.8$ and -14.1 respectively), while infauna were significantly more negative $(-15.7)$. There were also differences between the 2 bays. The Laguna Madre isotope ratios were heavier than the Alazan Bay ratios ( $p=0.0001$ ) when all groups were pooled.

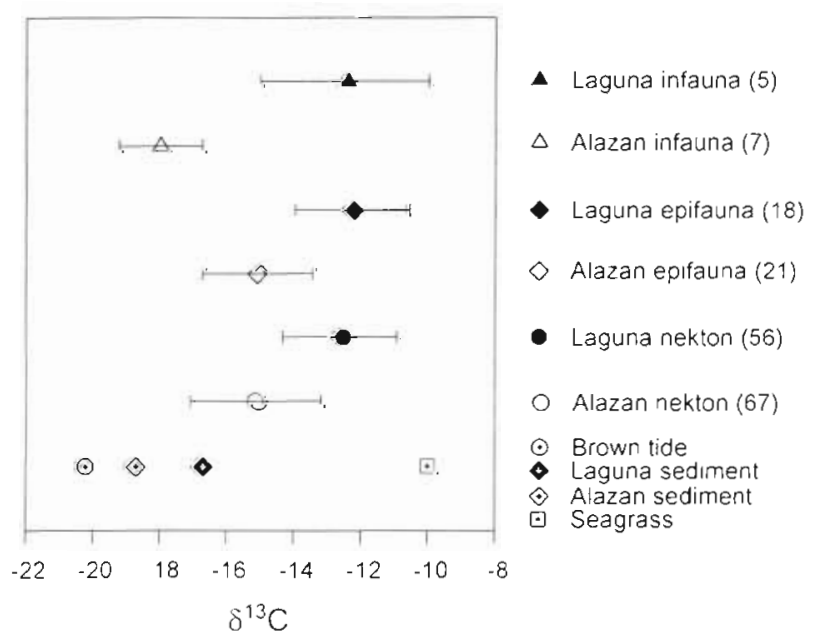

Fig. 3. Stable carbon isotope ratios for sources, macrofauna and fish by habitat group. Average and SD for all samples taken within a sampling area, with sample size in parentheses. Filled symbols: Laguna Madre; open symbols: Alazan Bay

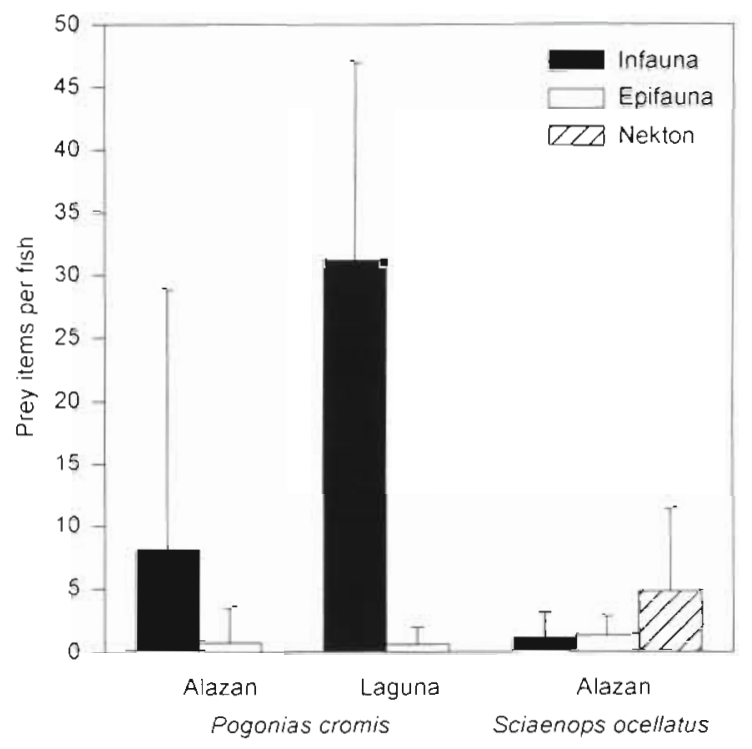

Fig. 4. Mean number of prey items by habitat group per fish found for the 2 dominant piscine predators by bay. Error bars show + SD

Alazan Bay values were significantly lighter than Laguna Madre values for infauna $(p=0.008)$, epifauna $(p=0.0001)$, and nekton ( $p=0.0001 ;$ Fig. 3$)$.

\section{Fish stomach contents}

Stomach contents for 19 black drum Pogonias cromis and 4 red drum Sciaenops ocellatus collected from gill nets were analyzed (Table 4). S. ocellatus $(30$ to $70 \mathrm{~cm}$ standard length) were collected only in Alazan Bay, but are usually common in Laguna Madre. P. cromis (20 to $50 \mathrm{~cm}$ standard length) were collected in both Alazan Bay and Laguna Madre. There was a prey species difference in $P$. cromis diets between the 2 bays (Table 4). Anomalocardia auberiana was the dominant prey taxa found in $P$. cromis stomachs in Laguna Madre, but was in much lower abundance in Alazan Bay (Table 4), reflecting sediment abundance patterns (Table 1). In Alazan, the dominant prey of P. cromis were the amphipods Grandidierella bonnieroides and Corophium louisianum (Table 4). However, there was no niche difference between $P$. cromis diets in the 2 bays (Fig. 4). In both bays, P. cromis ate infauna and epifauna, but not nekton. In contrast, guts of $S$. ocellatus contained primarily epifaunal and nektonic prey, including the bay anchovy Anchoa mitchilli and grass shrimp Palaemonetes sp. (Table 4). In general P. cromis and $S$. ocellatus appeared to exhibit niche separation in diet, with $P$. cromis having a more diverse diet than S. ocellatus (Fig, 4). 
Table 4. Number of prey items per fish for the 2 dominant piscine predators in the study bays. I: infauna; E: epifauna; N: nekton. $\mathrm{n}=$ number of replicates

\begin{tabular}{|c|c|c|c|c|c|c|c|}
\hline \multirow[t]{3}{*}{ Prey taxon } & \multirow[t]{3}{*}{ Prey habitat } & \multicolumn{4}{|c|}{ Pogonias cromis } & \multirow{2}{*}{\multicolumn{2}{|c|}{$\begin{array}{c}\text { Scieanops ocellatus } \\
\text { Alazan Bay } n=4\end{array}$}} \\
\hline & & \multicolumn{2}{|c|}{ Alazan Bay $\mathrm{n}=14$} & \multicolumn{2}{|c|}{ Laguna Madre $n=5$} & & \\
\hline & & Mean & $\mathrm{SD}$ & Mean & $\mathrm{SD}$ & Mean & $\mathrm{SD}$ \\
\hline \multicolumn{8}{|l|}{ Mollusca } \\
\hline Amygdalum papyrium & I & & & 0.40 & 0.55 & & \\
\hline Anomalocardia auberiana & I & 0.21 & 0.58 & 30.4 & 14.3 & & \\
\hline Ceritheum lutosum & $\mathrm{E}$ & & & 0.40 & 0.55 & & \\
\hline Diastoma varium & $\mathrm{E}$ & & & 0.40 & 0.89 & & \\
\hline Gastropod (unknown) & E & 0.64 & 2.13 & & & & \\
\hline Mulinia lateralis & I & & & & & & \\
\hline Tellina tampaensis & I & 0.29 & 0.83 & 0.40 & 0.89 & & \\
\hline \multicolumn{8}{|l|}{ Crustacea } \\
\hline Corophium louisianum & I & 1.79 & 3.87 & & & 0.25 & 0.50 \\
\hline Grandidierella bonnieroides & I & 5.21 & 13.9 & & & 0.75 & 1.50 \\
\hline Leptochelia rapax & I & 0.36 & 1.08 & & & & \\
\hline Palaemonetes sp. & $\mathrm{E}$ & 0.14 & 0.53 & 0.20 & 0.45 & & \\
\hline Palaemonetes vulgaris & $E$ & & & & & 1.3 & 1.5 \\
\hline \multicolumn{8}{|l|}{ Annelida } \\
\hline Polychaete (unknown) & I & 0.14 & 0.53 & & & & \\
\hline \multicolumn{8}{|l|}{ Osteichthyes } \\
\hline Anchoa mitchilli & $N$ & & & & & 1.25 & 2.50 \\
\hline Fish (unknown) & $\mathrm{N}$ & & & & & 3.50 & 4.04 \\
\hline
\end{tabular}

\section{DISCUSSION}

\section{Effect of brown tide on benthic communities}

The Texas brown tide event began in Alazan Bay in January 1990, had spread to Laguna Madre by June 1990. It is still persisting at the time of this writing. Species diversity was never very high in Alazan Bay or Laguna Madre due to hypersaline conditions (Conley 1996). Subsequent to the start of the brown tide, species diversity in both the planktonic and benthic communities became even lower (E. J. Buskey pers. comm.). Prior to the brown tide, Mulinia lateralis was the dominant benthic organism in Laguna Madre, with densities as high as $6000 \mathrm{~m}^{-2}$ (Martin 1979, Cornelius 1984, Montagna et al. 1993). In April 1991, M. lateralis was not present in Alazan Bay, and was found in relatively low abundance in Laguna Madre (Table 1). While benthic abundance was not significantly different between the 2 bays (Table 1), biomass (Table 2) and diversity were lower in Alazan Bay. The lower diversity in Alazan corresponds with lower seagrass biomass (Table 2). Seagrass habitats, in general, support more diverse communities than do bare bottom habitats (Stoner 1980, Summerson \& Peterson 1984). The species that were present in Alazan Bay, such as Streblospio benedicti and Capitella capitata (Table 1), are opportunistic in nature (Grassle \& Grassle 1974, McCall 1977). The paucity of seagrass beds and the presence of high wind mixing (Cornelius 1984) proba- bly contributed to the dominance of opportunistic species in Alazan Bay. The seagrass beds of Laguna Madre were dominated by less-opportunistic deposit feeders (e.g. Caecum pulchellum; Table 2) that were probably supported by the substantial flux of organic material to the sediments within the grass beds (Koepfler et al. 1993). Although some loss of abundance and diversity was probably related to the brown tide event, habitat differences between the 2 bays may also have accounted for differences in community structure.

\section{Stable carbon isotopes}

During the study period, there were only 2 major sources of carbon to the bays. Laguna Madre receives little freshwater inflow and has no direct river or creek drainage (Texas Department of Water Resources 1988); therefore, marshes and terrestrial runoff are not major sources of carbon. Laguna Madre is dominated by seagrass beds which cover $75 \%$ of the bay (Onuf 1996b). Benthic microalgal production was virtually non-existent after the onset of brown tide (Blanchard \& Montagna 1992). Therefore, phytoplankton, which was composed almost entirely of brown tide during the study period, and seagrass are the most important sources of carbon, although some primary consumers probably assimilate this carbon in the form of sediment organic matter. There was a clear phytoplankton sig- 
nature in Alazan Bay (Figs. 2 \& 3). Brown tide was the dominant species, so the isotope values are a result of the brown tide. The animals with signatures most closely resembling that of brown tide were the Alazan infauna, including filter feeders and deposit feeders (Figs. 2 \& 3). Filter and deposit feeders in the Laguna Madre had a more positive value (Fig. 2), more closely resembling seagrass detritus, suggesting that these species were probably suspension feeding on particulate organic matter at least partly derived from seagrass. This organic material was probably composed equally of seagrass detritus, which had the isotopic composition of living seagrass, and smaller particulate matter, which was composed of both brown tide and seagrass carbon (Fig. 2). Herbivores and predators in both bays were slightly heavier than deposit and filter feeders. The separation of $\delta^{13} \mathrm{C}$ values between bays was more evident for benthic infauna than it was for epifauna or fish (Flg. 3). This ditterence was due to deposit-feeding worms and amphipods that were relatively more negative (Table 3 ). When comparing individual species, the most striking differences between bays occur in the amphipods, which were as much as $6 \%$ apart (Table 3). While neither Alazan Bay nor Laguna Madre food webs were supported entirely by a single carbon source, phytoplankton- (i.e. brown tide) derived carbon was more important in Alazan Bay.

Comparing the current data to carbon isotope values measured before the onset of the brown tide indicates the relative influence of brown tide in the food web. Values that were lighter during the brown tide bloom than were reported before the bloom would indicate a shift towards phytoplankton influence that could be due to brown tide. In Laguna Madre, Fry \& Parker (1979) reported values of -8.8 for the killifish Fundulus spp. and -13.1 for the pinfish Lagodon rhomboides. After the brown tide, $\delta^{13} \mathrm{C}$ values lightened to -10.8 for Fundulus grandis and -13.3 for $L$. rhomboides (Table 3). Fry \& Sherr (1984) reported a mean value for various Laguna Madre fish species of -12.1 , which is similar to values from the present study (Fig. 3). A herbivore, the striped mullet Mugil cephalus lightened slightly, from -11.7 before brown tide (Fry \& Parker 1979) to -12.9 after brown tide (Table 3). So, fish carbon isotope ratios recorded during the current study are slightly lighter or the same as ratios from before the brown tide.

It is unlikely that migration or movement played an important role in the stable isotope values of fishes. No mass migration of fish in winter or during spring spawning periods has been found for black drum in any Texas Bay (Osburn \& Matlock 1984). Tagged fish are generally recaptured within the same bay that they are released in. For example, $78.2 \%$ of the black drum and $86.2 \%$ of the red drum are caught within the same bay that they are tagged and released in (Bowling 1996). The red and black drum can live a long time, but tissue turnover rates would have to be very slow for the fish signature to represent pre-brown tide conditions because the samples were taken 18 mo after onset of the tide. The fish isotope values are most likely due to local conditions within the previous couple of weeks or months, but this hasn't been tested directly.

Carbon isotope ratios of sediment were also measured before the onset of brown tide. Prior to the bloom. Laguna Madre sediments ranged from $-14.4 \%$ (Fry \& Parker 1979) to $-19 \%$ (Fry et al. 1977), while those in Baffin Bay were slightly more negative, -18 to $-19 \%$ (Fry et al. 1977). These values are comparable to those found in the present study (Fig. 3).

The lighter values in Baffin Bay and Alazan Bay indicate that the food web's reliance on phytoplankton carbon was not a result of the brown tide, but of the lack of extensive scagrass beds in Alazan Bay. However, it appears $\delta^{13} \mathrm{C}$ values either have not changed dramatically or are only slightly more negative between snapshot studies conducted before and after the onset of brown tide. Brown tide appears to have been incorporated into the food web and appears to be a suitable carbon source.

\section{Fish stomach contents}

There appears to be niche separation between the 2 large, predatory sciaenid species Sciaenops ocellatus and Pogonias cromis. Both fish fed on crustacean epifauna (Fig. 4, Table 4). However, $P$. cromis also fed on infaunal organisms, particularly bivalves, while $S$. ocellatus also fed in the water column on small fish. Previous studies have documented the large contribution of small bivalves, particularly Mulinia lateralis, but also Amygdalum papyrium, and Brachiodontes exustus, to the diet of $P$. cromis (Breuer 1962, Simmons \& Breuer 1962, Martin 1979). In the Laguna Madre, $M$. lateralis suffered a dramatic population decline corresponding to the onset of brown tide (Montagna et al. 1993), and very few were found in the current study (Table 1). In the absence of $M$. lateralis, black drum appeared to be feeding preferentially on another small bivalve, Anomalocardia auberiana (Table 3). A. auberiana were found in Laguna Madre sediment cores, but not in Alazan Bay (Table 1). In Alazan Bay, no small bivalves were found in the sediment cores. The absence of small bivalves (Table 1) may have caused $P$. cromis to switch to a diet dominated by small crustaceans in Alazan Bay (Table 4). In addition to the amphipods, abundance of Streblospio benedicti was high in Alazan Bay (Table 1). Although no S. benedicti were found in fish stomachs, it is unlikely that soft 
polychaete body parts would be preserved in gut contents. Several small gastropods that were most likely Ceritheum lutosum or Diastoma varium were found in $P$ cromis (Table 4). However, none of these snails were found in sediment cores in Alazan Bay (Table 1). Black drum were eating infaunal bivalves when available, and switching to infaunal amphipods and epifaunal gastropods in the absence of bivalves

The adult black drum population increased for $5 \mathrm{yr}$ prior to the brown tide, and reached 20 yr record levels during the brown tide (Texas Parks and Wildlife 1993). It has been suggested that increased predation from the black drum may have been partly responsible for the depleted populations of the dwarf surf clam $M u$ linia lateralis (Montagna et al. 1993). Since M. lateralis seems capable of assimilating brown tide in the laboratory (Montagna et al. 1993), the loss of M. lateralis may have facilitated the brown tide bloom. Based on stable isotopic analysis (Table 4) and current fish densities (Texas Parks \& Wildlife 1993), black drum seem capable of subsisting and even thriving on a brown tidebased food web.

\section{Food webs}

In Alazan Bay, brown tide was the dominant primary producer, driving both a planktonic and detrital food web (Fig. 5A). Additional minor carbon inputs may have come from Laguna Madre or the low terrestrial runoff. The benthos was composed only of polychaetes and amphipods (Table 1). The polychaetes consisted of the spionid facultative deposit feeders Streblospio benedicti and Polydora ligni. The amphipods Grandidierella bonnieroides and Corophium louisianum are both predominantly detritivores. Small, bottom
Fig. 5. Estuarine food webs suggested by stable isotope data and fish gut contents in (A) Alazan Bay and (B) Laguna Madre

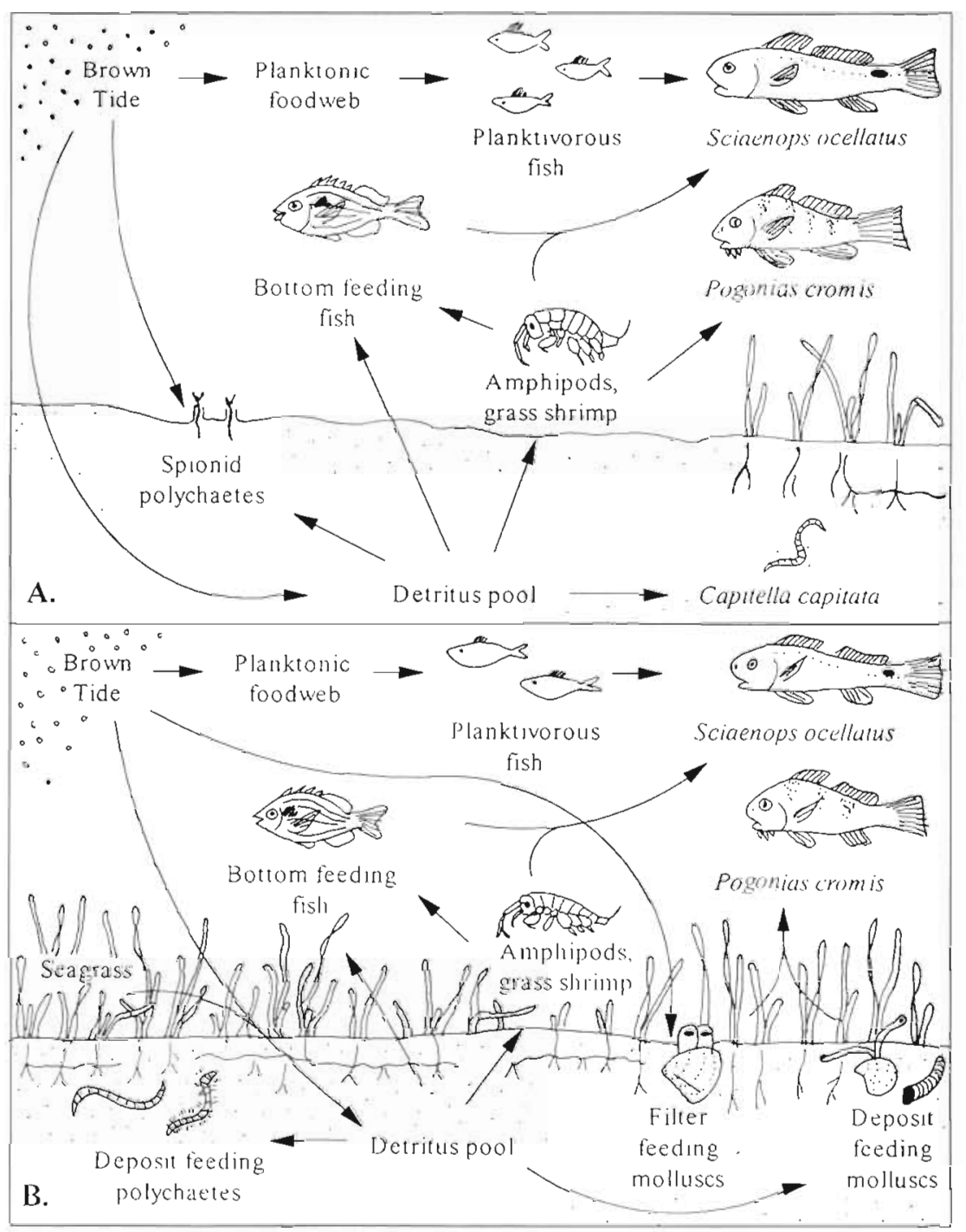


dwelling fish, including the goby Gobionellus boleosoma and the pinfish Lagodon rhomboides, were also supported by this detritus pool (Table 3), either by consuming detritus directly, consuming amphipods or polychaetes, or by consuming meiofauna (which were not sampled). The top predators in this system were sciaenid fishes. Pogonias cromis appeared to be eating predominantly amphipods and gastropods in Alazan Bay (Tables 3 \& 4). Sciaenops ocellatus fed on grass shrimp and planktivorous fishes. Planktivorous fish, e.g. the Gulf menhaden Brevoortia patronus and the silverside Membras martinica, were probably supported by a planktonic food chain that is based on brown tide as its carbon source (Table 3 ). Macrozooplankton grazers probably feed on the calanoid copepod Acartia tonsa (Buskey \& Stockwell 1993). A. tonsa incorporates brown tide carbon in winter and seagrass carbon in summer (Buskey pers. comm.). In general, the Alazan Bay food web was relatively simple, involving only a few species.

The Laguna Madre food web was more complex because of a higher species diversity (Table 1) and an additional carbon input (Fig. 5B). In this system, brown tide supported a planktonic food web, but the primary carbon source for benthos was seagrass (Table 3 ). The detritus pool supported several deposit-feeding polychaetes, including Haploscoloplos foliosus, and Capitella capitata (Table 1). In contrast to Alazan Bay, deposit-feeding and filter-feeding mollusks were present (Table 1). The filter-feeding mollusks, e.g. Anomalcardia auberiana, fed on brown tide (Table 4). Deposit-feeding mollusks, e.g. Caecum pulchellum were supported by the seagrass detrital pool (Table 4). These mollusks were the primary food source for the black drum (Table 4). The other top predator in the Laguna Madre was the red drum Sciaenops ocellatus, which fed primarily on planktivorous fish and grass shrimp (Table 4). The seagrass in Laguna Madre supplied both an additional carbon source and habitat complexity, which explains the high benthic productivity found in Laguna Madre (as indicated by high biomass; Table 2).

\section{Trophic role of brown tide}

The loss of species diversity associated with brown tide blooms has been well documented in many areas (Bricelj et al. 1987, Shumway 1990, Buskey \& Stockwell 1993, Buskey et al. 1997). Alazan Bay experienced this diversity loss, decreasing to just 6 benthic species (Conley 1996; Table 1). The species that remain appear to be able to incorporate brown tide. Therefore, the species that disappeared from Alazan Bay were either unable to incorporate brown tide or experienced allelopathy from the brown tide. In Laguna Madre, the loss of species diversity was not as dramatic (Conley 1996). The greatest difference between Alazan Bay and Laguna Madre is the presence of extensive seagrass beds in Laguna Madre. The seagrass beds may have prevented the loss of many species by offering habitat and an added food source, seagrass detritus.

The high cell density of the brown tide $\left(10^{9} \mathrm{l}^{-1}\right)$ decreased light available to producers for photosynthesis by some 60 to $70 \%$ (Dunton 1991, 1994), and $9.4 \mathrm{~km}^{2}$ of seagrass has been lost (Onuf 1996a). As a consequence, biomass of the dominant seagrass, Halodule wrightii, was reduced $50 \%$ (Dunton 1991, 1994). If the Texas brown tide persists or worsens, it is possible that there will be a large loss of seagrass biomass in Laguna Madre (Dunton 1991, Onuf 1996a, b). If this occurs, Laguna Madre may experience a loss of benthic species diversity similar to that observed for the mostly unvegetated Alazan Bay.

Currently, brown tide is not having direct effects on adult fish at the highest trophic level. However, fish are relatively long-lived animals and may not show a response to alteration at lower trophic levels for many years. Furthermore, although black drum seem able to subsist on a brown tide-dominated food web in Alazan Bay, brown tide might still affect fishes that rely on seagrass habitats by decreasing seagrass cover.

\section{Summary}

The replacement of a diverse estuarine phytoplankton community with a monoculture of brown tide has led to a loss of benthic diversity. The loss of benthic species could be due to the inability of certain species to incorporate brown tide or due to allelopathy. The species that prospered during the bloom had carbon isotope signatures similar to that of brown tide, indicating that brown tide was incorporated into the food web. At lower trophic levels, opportunistic amphipods and polychaetes appeared able to graze brown tide directly or feed on brown tide detritus. Higher trophic levels, such as some fish, altered their diets to consume those species that survived the brown tide bloom. The Laguna Madre food web, which was based on seagrass detritus and phytoplankton, was more diverse than the Alazan Bay food web, which was based predominantly on phytoplankton alone. If brown tide leads to a decease in seagrass cover by reducing light levels, the Laguna Madre ecosystem could come to resemble the Alazan Bay ecosystem. The 3 mechanisms by which brown tide could alter benthic community structure are: allelopathy, altering trophic pathways, or decreasing seagrass habitat by decreasing light levels. Trophic coupling may or may not be as efficient with brown 
tide as it would be with a diverse phytoplankton community, but brown tide is being incorporated into food webs.

Acknowledgements. We thank Rick Kalke for assistance in the field and expertise in identifying taxa, Antonio Mannino for assistance processing core samples, and Dick and Della Scalan for assistance in processing stable isotope samples. We thank the Texas Parks Wildlife Department Coastal Fisheries Division for their samples from gill nets. This manuscript is dedicated to the memory of Joe Martin, who provided assistance in the field. This material is based (in part) upon work supported by the Texas Higher Education Coordinating Board, Advanced Technology Program under Grant No. 4541 (and 3658-264). Contribution no. 1009 of the University of Texas Marine Science Institute.

\section{LITERATURE CITED}

Andersen RA, Saunfers GW, Paskind GW, Sexton JP (1993) Ultrastructure and 18S rRNA gene sequence for Pelagomonas calceolata gen. et $\mathrm{sp}$. nov. and the description of a new algal class, the Pelagophyceae classis nov. J Phycol 29:701-715

Blanchard GF, Montagna PA (1992) Photosynthetic response of natural assemblages of marine benthic microalgae to short- and long-term variations of incident irradiance in Baffin Bay, Texas. J Phycol 28:7-14

Bowling BG (1996) A summary of fish tagging on the Texas coast: November 1975-December 1993. Management Data Series No. 126, Texas Parks and Wildlife Dept, Austin, TX

Breuer JP (1962) An ecological survey of the lower Laguna Madre of Texas. Publ Inst Mar Sci 8:153-183

Bricelj VM, Epp J, Malouf RE (1987) Intraspecific variation in reproductive and somatic growth cycles of bay scallops Argopecten irradians. Mar Ecol Prog Ser 36:123-137

Bricelj VM, Kuenstner SH (1989) Effects of the 'brown tide' on the feeding physiology and growth of bay scallops and mussels. In: Cosper EM, Bricelj VM, Carpenter EJ (eds) Coastal and estuarine studies. Springer-Verlag. Berlin, p 491-509

Buskey EJ, Montagna P, Amos A, Whitledge TE (1997) Disruption of grazer populations as a contributing factor to the initiation of the Texas brown tide algal bloom. Limnol Oceanogr (in press)

Buskey EJ, Stewart S, Peterson J, Collumb C (1996) Current status and historical trends of brown tide and red tide phytoplankton blooms in the Corpus Christi Bay National Estuary Program study area. CCNEP Report No. 01:1-90

Buskey EJ, Stockwell DA (1993) Effects of a persistent 'brown tide' on zooplankton populations in the Laguna Madre of south Texas. In: Smayda TJ, Shimizu Y (eds) Toxic phytoplankton blooms in the sea. Elsevier Science Publishers, Amsterdam, p 659-666

Conley MF (1996) Effect of a persistent brown tide bloom on macroinfaunal communities in Baffin Bay and Laguna Madre, Texas. MS thesis. The University of Texas

Cornelius SE (1984) An ecological survey of Alazan Bay, Texas. Technical Bulletin No. 5. Texas A and I University, Kingsville

Cosper EM, Dennison WC, Carpenter EJ, Bricelj VM, Mitchell JG, Kuenstner SH, Colflesh D, Dewey M (1987) Recurrent and persistent brown tide blooms perturb coastal marine ecosystem. Estuaries 10:284-290
Craig $H(1957)$ Isotopic standards for carbon and oxygen and correction factors for mass-spectrophotometric analysis of carbon dioxide. Geochim Cosmochim Acta 12:133-149

DeYoe HR, Suttle DA (1994) The inability of the Texas "brown tide' alga to use nitrate and the role of nitrogen in the initiation of a persistent bloom of this organism. J Phycol 30: $800-806$

Draper C, Gainey L, Shumway S. Shapiro L (1989) Effects of Aureococcus anophagefferens ('Brown tide') on the lateral cilia of 5 species of bivalve mollusks. In: Graneli E, Sundstrom B, Edler L, Andersen DM (eds) Toxic marine phytoplankton. Elsevier, New York, p 128-313

Dunton $\mathrm{KH}$ (1991) The effect of extended periods of low light on growth and photosynthesis in the seagrass Halodule wrightii. ln: Whitledge TE, Pulich WM Jr (eds) Report: brown tide symposium and workshop, 15-16 July 1991 The University of Texas Marine Science Institute, Tech Rep No. TR/91-002, Port Aransas

Dunton KH (1994) Seasonal growth and biomass of the subtropical seagrass Halodule wrightii in relation to continuous measurements of underwater irradiance. Mar Biol 120:479-489

Fry B, Parker PL (1979) Animal diet in Texas seagrass meadows: $\delta^{13} \mathrm{C}$ evidence for the importance of benthic plants. Estuar Coast Mar Sci 8:499-509

Fry B, Scalan RS, Parker PL (1977) Stable carbon isotope evidence for two sources of organic matter in coastal sediments: seagrasses and plankton. Geochim Cosmochim Acta 41:1875-1877

Fry B, Sherr E (1984) $\delta^{13} \mathrm{C}$ measurements as indicators of carbon flow in marine and freshwater ecosystems. Contrib Mar Sci 27:13-47

Gainey LF, Shumway SE Jr (1991) The physiological effect of Aureococcus anophagefferens ('brown tide') on the lateral cilia of bivalve mollusks. Biol Bull 181:298-306

Grassle JF, Grassle JP (1974) Opportunistic life histories and genetic systems in marine benthic polychaetes. J Mar Res $32: 253-284$

Javor B (1989) Hypersaline environments. Springer-Verlag, New York

Jewett-Smith J (1991) Factors influencing the standing crop of diatom epiphytes of the seagrass Halodule wrightii in South Texas seagrass beds. Contrib Mar Sci 32:27-39

Koepfler ET, Benner R, Montagna PA (1993) Variability of dissolved organic carbon in sediments of a seagrass bed and an unvegetated area within an estuary in southern Texas. Estuaries 16:391-404

Martin JJ (1979) A study of the feeding habits of the black drum (Pogonias cromis Linnaeus) in Alazan Bay and the Laguna Salada, Texas. MS thesis, Texas A and I University, Kingsville

McCall PL (1977) Community patterns and adaptive strategies of the infaunal benthos of Long Island Sound. J Mar Res 35:221-266

Montagna PA, Stockwell DA, Kalke RD (1993) Dwarf surfclam Mulnia lateralis (Say, 1822) populations and feeding durng the Texas brown tide event. J Shellfish Res 2: $433-442$

Onuf CP (1996a) Seagrass responses to long-term light reduction by brown tide in upper Laguna Madre, Texas: distribution and biomass patterns. Mar Ecol Prog Ser 138: $219-231$

Onuf CP (1996b) Biomass patterns in seagrass meadows of the Laguna Madre, Texas. Bull Mar Sci 58:404-420

Osburn HR, Matlock GC (1984) Black drum movement in Texas bays. N Am J Fish Manag 4:523-530

Parker PL (1964) The biogeochemistry of the stable isotopes 
of carbon in a marine bay. Geochim Cosmochim Acta 28: $1155-1164$

SAS Institute Inc (1991) SAS/STAT guide for personal computers, version 6. SAS Institute Inc, Cary, NC

Shumway SE (1990) A review of the effects of algal blooms on shellfish and aquaculture. J World Aquaculture Soc 21. $65-104$

Simmons EG, Breuer JP (1962) A study of redfish, Sciaenops ocellatus Linnaeus and black drum, Pogonias cromis Linnaeus. Report No. 49 of the Texas Game and Fish Commission Marine Laboratory, Rockport, p 184-211

Sofer $Z$ (1980) Preparation of carbon dioxide for stable carbon isotope analysis of petroleum fractions. Analyt Chem 52 $1389-1391$

Stockwell DA, Buskey EJ, Whitledge TE (1993) Studies on conditions conducive to the development and maintenance of a persistent 'brown tide' in Laguna Madre, Texas. In: Smayda TJ, Shimizu Y (eds) Toxic phytoplankton blooms in the sea. Elsevier Science Publishers, Amsterdam, p 693-698

Stoner AW (1980) The role of seagrass biomass in the organization of benthic macrofaunal assemblages. Bull Mar Sci $30.537-551$

Summerson HC, Peterson CH (1984) The role of predation in

This article was presented by K. R. Tenore (Senior Editorial Advisor), Solomons, Maryland, USA organizing benthic communities of a temperate-zone seagrass bed. Mar Ecol Prog Ser 15:63-77

Texas Department of Water Resources (1988) The influence of freshwater inflows upon the major bays and estuaries of the Texas Gulf coast, Vol. 8, Executive summary (2nd edn). Texas Department of Water Resources, Austin

Texas Parks and Wildlife Department (1993) Trends in relative abundance and size of selected finfishes and shellfishes along the Texas coast: November 1975-December 1991 Texas Parks and Wildlife Department, Management Data Series 103, Austin

Tracey GA (1988) Feeding reduction, reproductive failure, and mortality in Mytilus edulis during the 1985 'brown tide' in Naragansett Bay, Rhode Island. Mar Ecol Prog Ser 50:73-81

Tracey G, Steele R, Wright L (1990) Variable toxicity of the brown tide organism, Aureococcus anophagefferens, in relation to environmental conditions for growth. In: Granelı E, Sundstrom B, Edler L, Andersen DM (eds) Toxic marine phytoplankton. Elsevier, New York, p 233-237

Trust BA (1993) Stable carbon and sulfur isotopic ratios in migrating redhead ducks (Aythya americana) in their breeding and winlening habitats. Doctoral dissertation, University of Texas at Austin

Manuscript furst received: May 10, 1995

Revised version accepted: April 16, 1997 